\title{
Experimental Study of Heat Transfer in a Real Scale Building Incorporating PCM in the Air Layer of the Vertical Walls
}

\author{
Zahra Najam, Mustapha El Alami*, Mostafa Najam \\ Laboratory of Physical Materials, Microelectronics, Automatics and Heat Transfer (LPMMAT), Faculty of Sciences, Hassan II \\ University of Casablanca, Casablanca, Morocco \\ Email: *mustapha.elalami@univh2c.ma, *elalamimus@gmail.com
}

How to cite this paper: Najam, Z., El Alami, M. and Najam, M. (2019) Experimental Study of Heat Transfer in a Real Scale Building Incorporating PCM in the Air Layer of the Vertical Walls. Journal of Power and Energy Engineering, 7, 14-25. https://doi.org/10.4236/jpee.2019.75003

Received: April 19, 2019

Accepted: May 21, 2019

Published: May 24, 2019

Copyright $\odot 2019$ by author(s) and Scientific Research Publishing Inc. This work is licensed under the Creative Commons Attribution International License (CC BY 4.0).

http://creativecommons.org/licenses/by/4.0/

\begin{abstract}
The purpose of this paper is to study the energy efficiency of a local living space exposed to solar radiation in the subtropical climate of Casablanca. The study was mainly focused on the contribution of a phase change material (PCM), inserted into a 7-cm thick air layer of a double brick wall, in two different locations. We note that the experimental study was conducted using two real-scale test cavities, located in the Faculty of Science Ain Chock-Casablanca. Two PCM mounting methods were used for the south and west walls, in order to test its energy efficiency as a storage and retrieval means of the solar flux coming from the outside. In the case of the southern wall, the PCM is put directly on the internal side of the outside part of the double wall (Case 1). For the west wall, the PCM is placed $1.2 \mathrm{~cm}$ away from the internal side of the outer part of the double wall (Case 2). The first result shows that the PCM placed to the wall allows storing the solar heat during the day and releasing it to the outside of the building at night. While in the second case, the PCM keeps the heat stored day and night.
\end{abstract}

\section{Keywords}

Experimental Study, Heat Transfer, PCM, Air Layer, Real-Scale Building

\section{Introduction}

The energy consumption in the buildings rises increasingly, housing and tertiary buildings are responsible for the consumption of approximately $25 \%$ of the total energy consumption and 33\% of electricity consumption in Morocco. The main disadvantage of light weight buildings concerning thermal comfort and energy consumption is their low thermal energy storage potential in walls [1]. 
Thermal insulation is an important technology to reduce energy consumption in buildings by preventing heat gain/loss through the building envelope: a powerful thermal insulation can reduce the energy consumption in heating and cooling by $60 \%$. Elamin [2] has shown that the optimal choice of lake building orientation, the glazing ratio, the air layer thickness, the mass flow rate ventilation for fresh air can contribute significantly in reducing the heating consumption in winter and air conditioning in summer. Bekkouche et al. [3] have addressed one of the main parameters that affect the thermal resistance of a double wall separated by an air layer. The thermal resistance of the air layer can be equivalent to a conventional thermal insulation layer.

Building envelope thermal insulation is a proven technology that contributes to energy efficient buildings. The new trend that has recently been observed in the development of thermal insulation is the development of phase change materials (PCMs). Phase change materials (PCM) are a high heat-melting substance that can store and release large amounts of energy. The principle is based on the latent heat storage. As the temperature increases, the temperature of a latent heat accumulator does not increase, but the medium changes from one physical state to another and thus stores energy. Therefore, the energy intake cannot be detected by touch. The temperature only increases detectably after a complete phase change. When a change occurs, the latent heat involved is equal to the heat of fusion or crystallization of the storage medium. The advantage of PCM is that it is possible to store large amounts of heat or cold in small temperature ranges [4]. Several review papers have been published on the concept of using PCM in the building envelope: walls [5] [6] [7] [8] [9], ceilings [10] [11] [12], floors [13] [14] and windows.

Previous works show that several experimental studies have focused on the building thermal efficiency. Using PCM material in such building walls can decrease the temperature fluctuations, particularly in case of solar radiations loads. It is then a potential method for reducing energy consumption in passively designed buildings. This tendency is confirmed by numerous papers. Mourid et al. [9] [15] carried out an experimental thermal study using two identical real scale cells: One is equipped with PCM layer installed on the roof and/or in vertical walls. Authors notice a reduction of transmitted flux density from the ceiling to the cavity of $56.8 \%$ in the case of a single thickness of PCM layer, and of $88 \%$ with double layer of PCM, Compared with a reference cavity. Two test houses with a classic residential construction showed that the introduction of $1.27 \mathrm{~cm}$ of PCM wall panel in the west wall reduced maximum heat flux by $29.7 \%$, while the optimal location of $2.54 \mathrm{~cm}$ of PCM wall panel in the southern wall reduced maximum heat flux by $51.3 \%$, Lee et al. [16].

Our contribution is a part of this policy of energy efficiency in the Moroccan sector. For this purpose, we will carry out an experimental investigation on the use of MCP to improve the phenomenon of inertia of the walls, Figure 1. We present in the first the results of a passive comparative study between two cavities: one of reference and the other with PCM. The originality of our study resides 


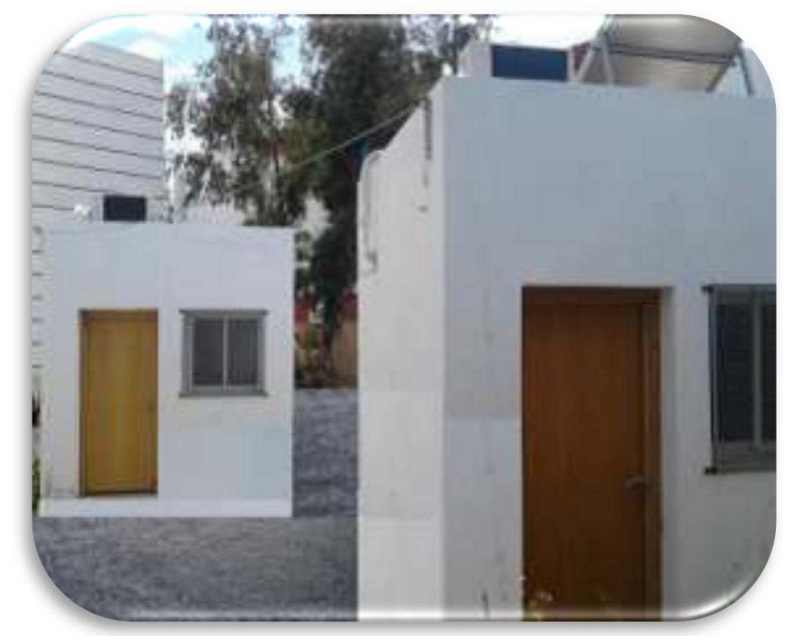

Figure 1. View of the experimental cells.

in the incorporation of two modes, of the MCP within the blades of air from the south and west walls of a real scale local exposed to the weather conditions of Casablanca. The objective of this study is to evaluate the thermal performance of residential walls equipped with a phase change material in the air layer during summer.

\section{Description of the Experimental Set-Up}

\subsection{Experimental Protocol}

The experimental setup is located in the Faculty of Sciences Ain Chock (FSAC) in Casablanca $\left(33^{\circ} 36^{\prime} \mathrm{N}, 07^{\circ} 36^{\prime} \mathrm{W}\right)$. It is composed of two real scale cavities, Figure 1, identical with the same orientations and dimensions. The dimensions of one cell are $3 \mathrm{~m}$ width, $3 \mathrm{~m}$ length and $3 \mathrm{~m}$ high. The northern wall is equipped with a simple class window of $1 \mathrm{~m} \times 1 \mathrm{~m}$ and a wood door of $2 \mathrm{~m} \times 1 \mathrm{~m}$. The vertical walls are identical except for the western and southern wall of the PCM-cavity, for which we introduced a $5.25 \mathrm{~mm}$ PCM layer in its air layer as indicated in Table 1. Two cases are envisaged for this study depending on the location of the PCM layer as shown in Figure 2 (Case 1) and Figure 3 (Case 2).

\subsection{Phase Change Material}

The product tested, Energain ${ }^{\circledR}$, developed by the DuPont ${ }^{\mathrm{TM}}$ de Nemours Society. It is obtained from a mixture of a solid compound copolymer (ethylene, 40\%) and paraffin $(60 \%)$. It is encapsulated, in panels $\left(1 \times 1.2 \times 0.0056 \mathrm{~m}^{3}\right)$, by using thin Aluminum coverage. The form of the PCM material is flexible sheets of 5.26 $\mathrm{mm}$ thickness, with a melting temperature between $20^{\circ} \mathrm{C}$ to $35^{\circ} \mathrm{C}$ [17], which density is about $900 \mathrm{~kg} \cdot \mathrm{m}^{3}$. The properties of this PCM are shown in Table 2.

\subsection{Weather Data}

The weather data used in this study are those relating to September 2017, measured using the weather station installed on the roof of the FSAC. The latter was 
Table 1. Composition of the walls with and without PCM and thermo-physical properties of the materials.

\begin{tabular}{|c|c|c|c|}
\hline $\begin{array}{c}\text { Walls } \\
\text { (compositions } \\
\text { and thickness) }\end{array}$ & Without PCM & $\begin{array}{l}\text { With PCM } \\
\text { (West wall) }\end{array}$ & $\begin{array}{l}\text { With PCM } \\
\text { (South wall) }\end{array}$ \\
\hline Vertical Walls & $\begin{array}{c}1 \mathrm{~cm} \text { concrete mortar } \\
7.2 \mathrm{~cm} \text { alveolar bricks } \\
12.6 \mathrm{~cm} \text { air layer } \\
7.2 \mathrm{~cm} \text { alveolar bricks } \\
1 \mathrm{~cm} \text { concrete mortar }\end{array}$ & $\begin{array}{c}1 \mathrm{~cm} \text { concrete mortar } \\
7.2 \mathrm{~cm} \text { alveolar bricks } \\
1.5 \mathrm{~cm} \text { concrete mortar } \\
1.2 \mathrm{~cm} \text { air layer } \\
0.526 \mathrm{~cm} \text { PCM panel } \\
8.3 \mathrm{~cm} \text { air layer } \\
7.2 \mathrm{~cm} \text { alveolar bricks } \\
1 \mathrm{~cm} \text { concrete mortar }\end{array}$ & $\begin{array}{c}1 \mathrm{~cm} \text { concrete mortar } \\
7.2 \mathrm{~cm} \text { alveolar bricks } \\
1.5 \mathrm{~cm} \text { concrete mortar } \\
0.526 \mathrm{~cm} \text { PCM panel } \\
9.5 \mathrm{~cm} \text { air layer } \\
7.2 \mathrm{~cm} \text { alveolar bricks } \\
1 \mathrm{~cm} \text { concrete mortar }\end{array}$ \\
\hline Ceiling & & $\begin{array}{l}2 \mathrm{~cm} \text { concrete mortar } \\
3 \mathrm{~cm} \text { bitumen } \\
2 \mathrm{~cm} \text { concrete mortar } \\
15 \mathrm{~cm} \text { heavy concrete } \\
2 \mathrm{~cm} \text { concrete mortar }\end{array}$ & \\
\hline Floor & & $\begin{array}{c}5 \mathrm{~cm} \text { concrete mortar } \\
3 \mathrm{~cm} \text { clay } \\
2 \mathrm{~cm} \text { de polystyrene } \\
4 \mathrm{~cm} \text { concrete } \\
10 \mathrm{~cm} \text { limestone }\end{array}$ & \\
\hline
\end{tabular}

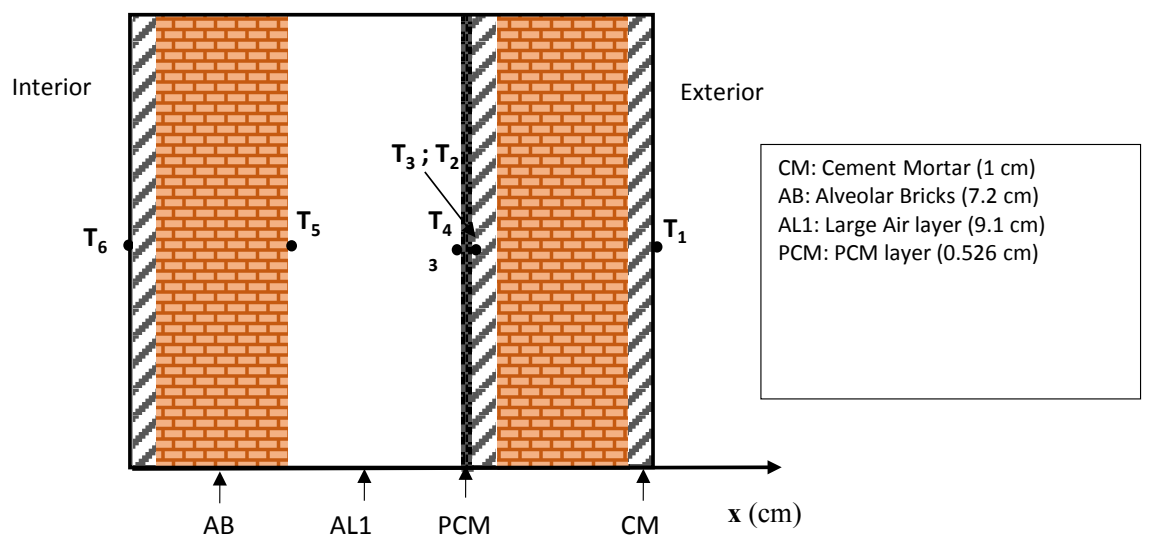

Figure 2. Southern wall composition and thermocouples positions (Case 1).

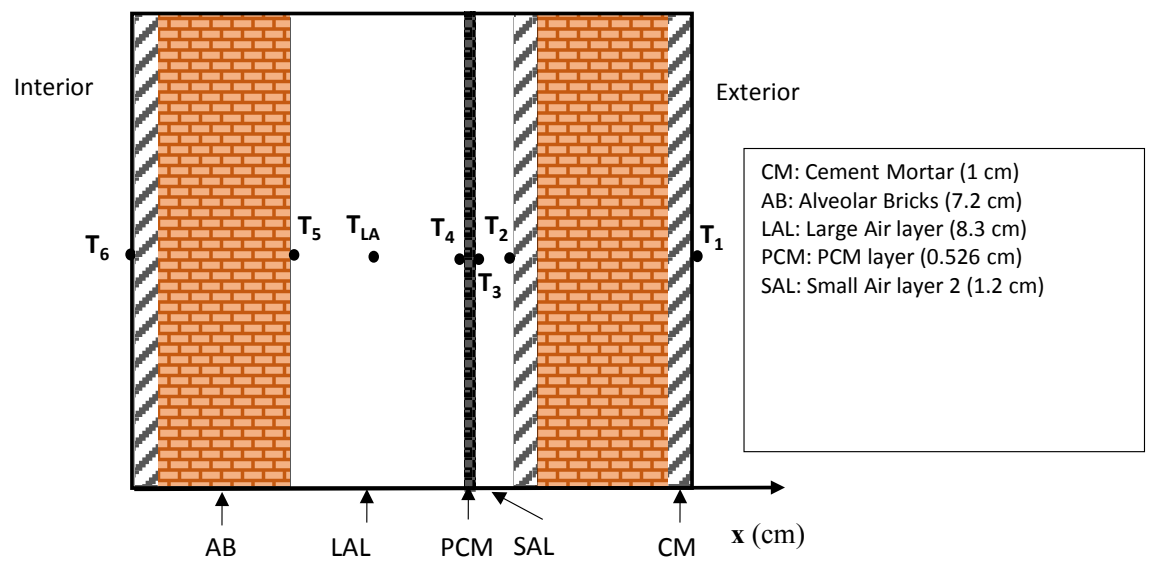

Figure 3. Western wall composition and thermocouples positions (Case 2). 
Table 2. PCM thermal properties.

\begin{tabular}{cc}
\hline Thermal conductivity (solid phase) & $0.18 \mathrm{~W} /(\mathrm{m} \cdot \mathrm{K})$ \\
Thermal conductivity (liquid phase) & $0.22 \mathrm{~W} /(\mathrm{m} \cdot \mathrm{K})$ \\
Latent heat of fusion $\left(5^{\circ} \mathrm{C}-30^{\circ} \mathrm{C}\right)$ & $72 \mathrm{~kJ} / \mathrm{kg}$ \\
Total heat storage capacity (temperature range $0^{\circ} \mathrm{C}$ to $\left.30^{\circ} \mathrm{C}\right)$ & $\sim 140 \mathrm{~kJ} / \mathrm{kg}$ \\
\hline
\end{tabular}

used to register the outdoor temperature, solar radiation, wind velocity and relative humidity. These data were measured with a time step of one hour.

The global heat radiation and the external temperature are presented in Figure 4 . Note that for this period, the global solar radiation is practically identical for the three days of measurement. Its maximum value is around $709 \mathrm{~W} / \mathrm{m}^{2}$. The external temperature fluctuations vary between $19.3^{\circ} \mathrm{C}$ and $28^{\circ} \mathrm{C}$. These fluctuations will act on the thermal resistance of the walls.

\section{Analysis of Comparative Thermal Performances}

This section presents an analysis of the thermal performances of the PCM wallboards. In this study, we evaluate the results generated through two different cases. The existence of the PCM composite in the walls is the main factor that differs both cases. We get the room air temperature (Figure 5), and the temperature average of the interior and exterior surfaces of both western and southern walls (Figure 6). These data are extracted in both cases, evaluated, and then compared.

\subsection{Ambient Temperatures of the Cells}

In Figure 5, we extract the room temperature $\mathrm{T}_{\mathrm{am}}$ from the cell that has PCM and the cell without PCM, and then we compare the results. For the cavity with $\mathrm{PCM}$, the ambient temperature varies between $25.5^{\circ} \mathrm{C}$ and $31^{\circ} \mathrm{C}$, whereas, the temperature fluctuates from $23.8^{\circ} \mathrm{C}$ to $28^{\circ} \mathrm{C}$ in the cells without PCM. The results show that the integration of $5.25 \mathrm{~mm}$ thick PCM panels inside the southern and western walls can increase the maximum fluctuation of the temperature by $3.2^{\circ} \mathrm{C}$. It is important to note that during the night the same phenomenon is observed with a difference of $1.7^{\circ} \mathrm{C}$. This can be explained by the energy released by the PCM during the solidification of the phase change material at night time. However, the results show that the ambient temperature in the cell with PCM is higher than the one without PCM. Indeed, the heat that enters through the ceilings of the two cells is not released outside with the same intensity. Because the thermal resistance in the southern and western walls that contain PCM is higher than the walls in the cell without MCP.

\subsection{Mean Temperatures of the Interior Surfaces}

Figure 6 shows the evolutions of mean temperatures for the interior and exterior surfaces of the two modified walls, for the cases with and without PCM. Data analysis shows that the mean temperature of the interior surface of western 


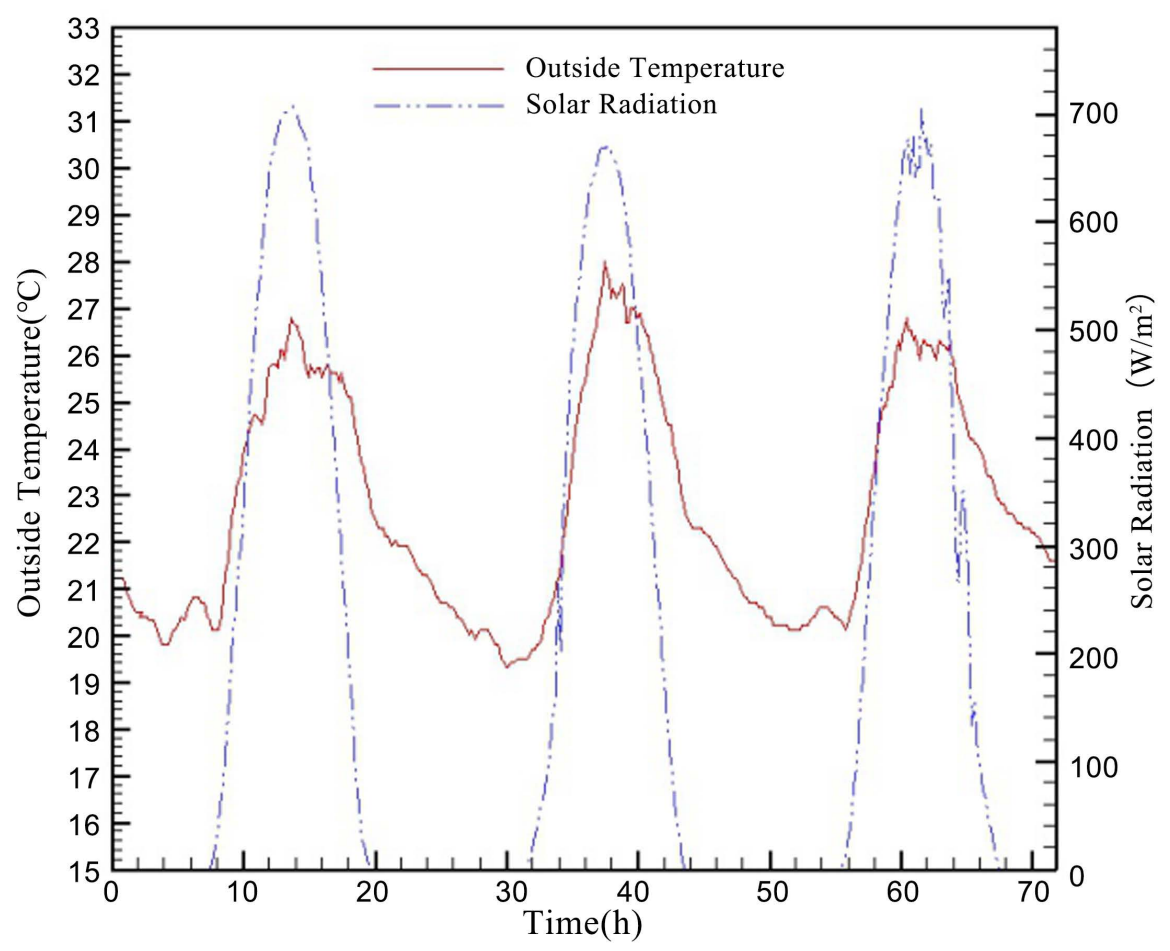

Figure 4. Time wise variations of the external temperature and global solar radiation.

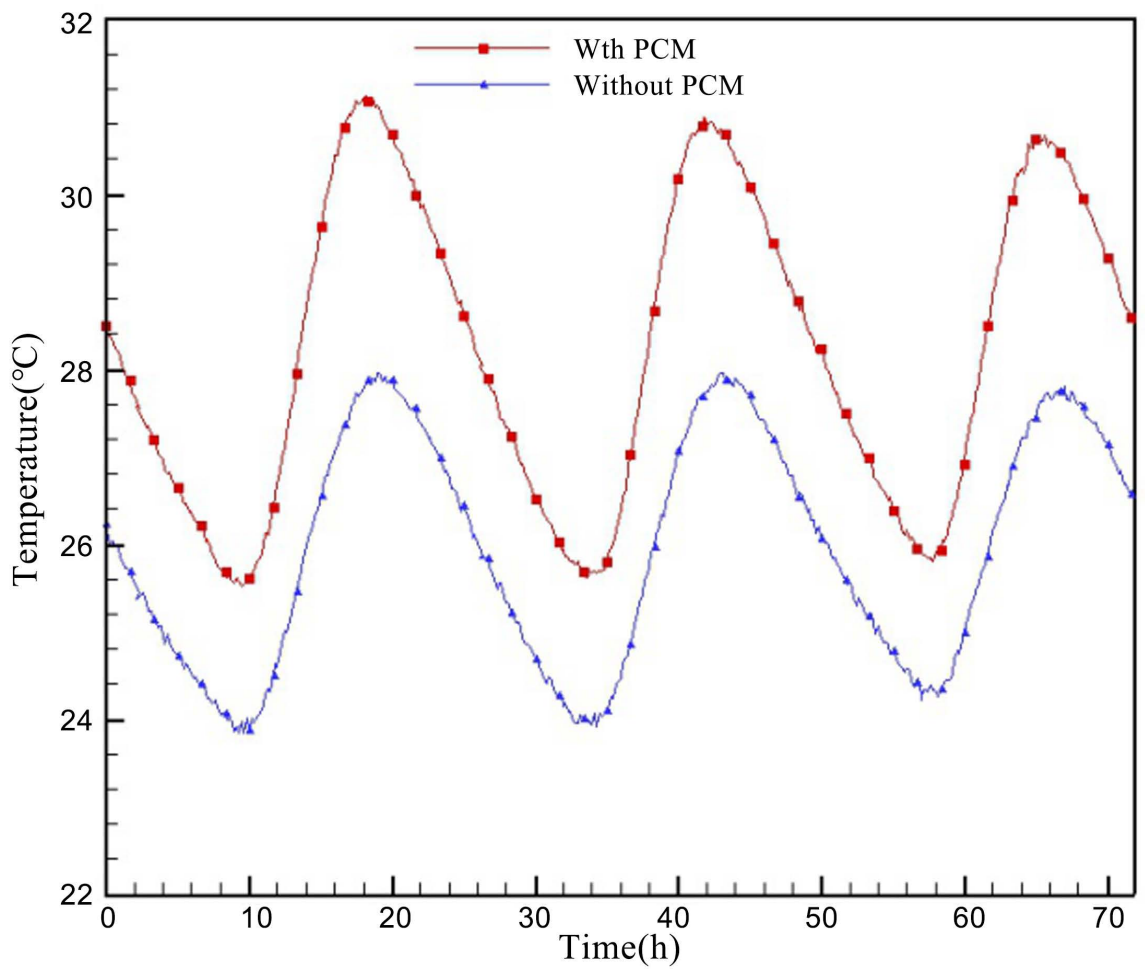

Figure 5. Time variations of the ambient temperatures of the cells with and without PCM.

wall for the case without PCM fluctuated from $23.3^{\circ} \mathrm{C}$ to $27.7^{\circ} \mathrm{C}$, whereas for the PCM case it is varying from $27.2^{\circ} \mathrm{C}$ to $31.6^{\circ} \mathrm{C}$. It proves that the PCM wall can 

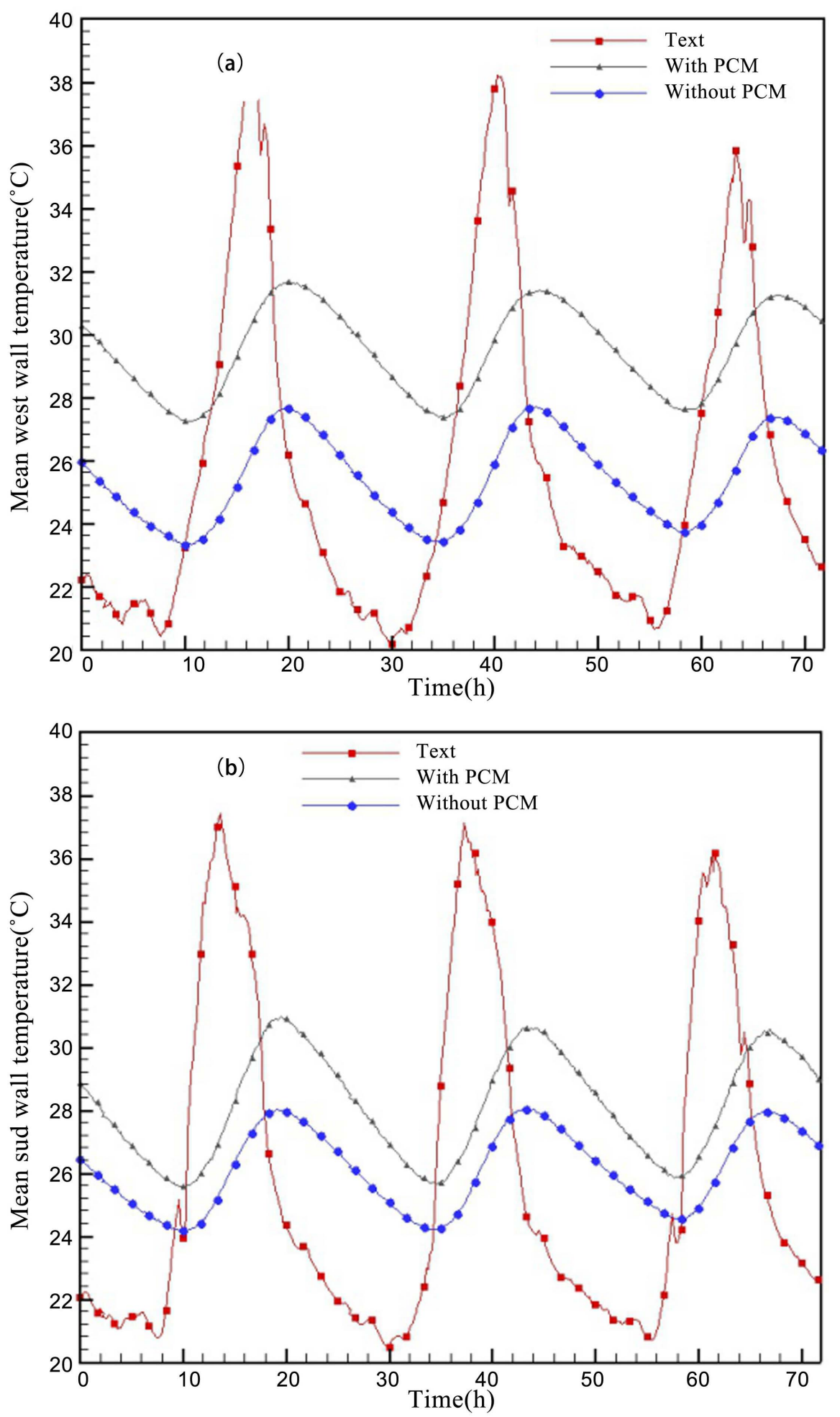

Figure 6. Experimental mean temperatures of the interior surfaces of western wall (a), southern wall (b).

increase the temperature fluctuations by $4^{\circ} \mathrm{C}$ in our tests. As against the mean temperature of the interior surface of southern wall without PCM fluctuated from $24.2^{\circ} \mathrm{C}$ to $28^{\circ} \mathrm{C}$, whereas for the PCM case it is varying from $25.5^{\circ} \mathrm{C}$ to 
$31^{\circ} \mathrm{C}$. It proves that the PCM wall can increase the temperature fluctuations by $3^{\circ} \mathrm{C}$ the day and $1.3^{\circ} \mathrm{C}$ during the night.

\section{Thermal Behavior of the Wall with PCM for the Two Cases}

In this paragraph, we focus on the thermal behavior of the air layer. First, we started with Case 1 (southern wall): MCP is fixed directly on the internal face of the exterior wall of the double wall and then we will proceed with Case 2 (western wall): the MCP is placed at $1.2 \mathrm{~cm}$ from the internal face of the exterior wall of the double wall, for the period of September $23^{\text {th }}$ to $25^{\text {th }}, 2017$.

\subsection{Case 1: PCM in the Southern Wall}

Figure 7 shows the temperature variations of the southern wall faces (Case 1). The behavior of the PCM glued to the internal face of wall 1 (Figure 2) resulted in a different temperature spectrum. Indeed, the temperature of the internal face of the external wall $\left(\mathrm{T}_{2}\right)$ is identical to that of the MCP $\left(\mathrm{T}_{3}\right)$; the two curves related to these temperatures are mixed. This resulted in a total releasing of the latent heat of the PCM at night. Thus, the phenomenon of the thermal inertia expected from the use of the PCM is no longer ensured. That shows that Case 1 has some limitations compared to Case 2 . The analysis of the temperature profile of the walls shows that for a period of the day, all the components of the wall are practically at the same temperature. Indeed, the PCM heated directly by the outer wall transmits this heat flow by convection within the LAGE to the inner wall of the studied wall.

\subsection{Case 2: PCM in the Western Wall}

Figure 8 illustrates the temporal variation of the temperatures of each face of the interior and exterior walls of the western double wall, as it was defined in Figure 3 , for the same period as Case 1. It is noted that the heat flux density coming from the external face is absorbed by both the MCP and the interior wall as can be seen on their temperature variations.

It is also noted that the temperature $\mathrm{T}_{2}$ of the internal face of the external wall is lower than the temperature of the other sides. In the time range between $12 \mathrm{~h} 00$ with $20 \mathrm{~h} 00$ (during the day) $\mathrm{T}_{2}$ is equal to the temperatures $\mathrm{T}_{3}$ and $\mathrm{T}_{4}$ of the CPM which are almost mixed because of the conjugated phenomenon of the radiation and the conduction. They present a temperature difference during the night due to the MCP inertia phenomenon and the thin air gap (LAFE) which acts as a thermal insulator. The temperature difference is $1.5^{\circ} \mathrm{C}$.

The same phenomenon is observed for the temperatures of the inner wall sides. The variation of the temperature $\mathrm{TLA}_{07}$, in the middle of the large tick air layer (LAGE), between the temperatures $T_{4}$ and $T_{5}$ of the wall sides, shows the existence of a thermal gradient within it. This shows the existence of convection flows between the outer face of the inner wall and MCP, which increases at night. It can be deduced that the temperature $T_{2}$ is influenced by the ambient 


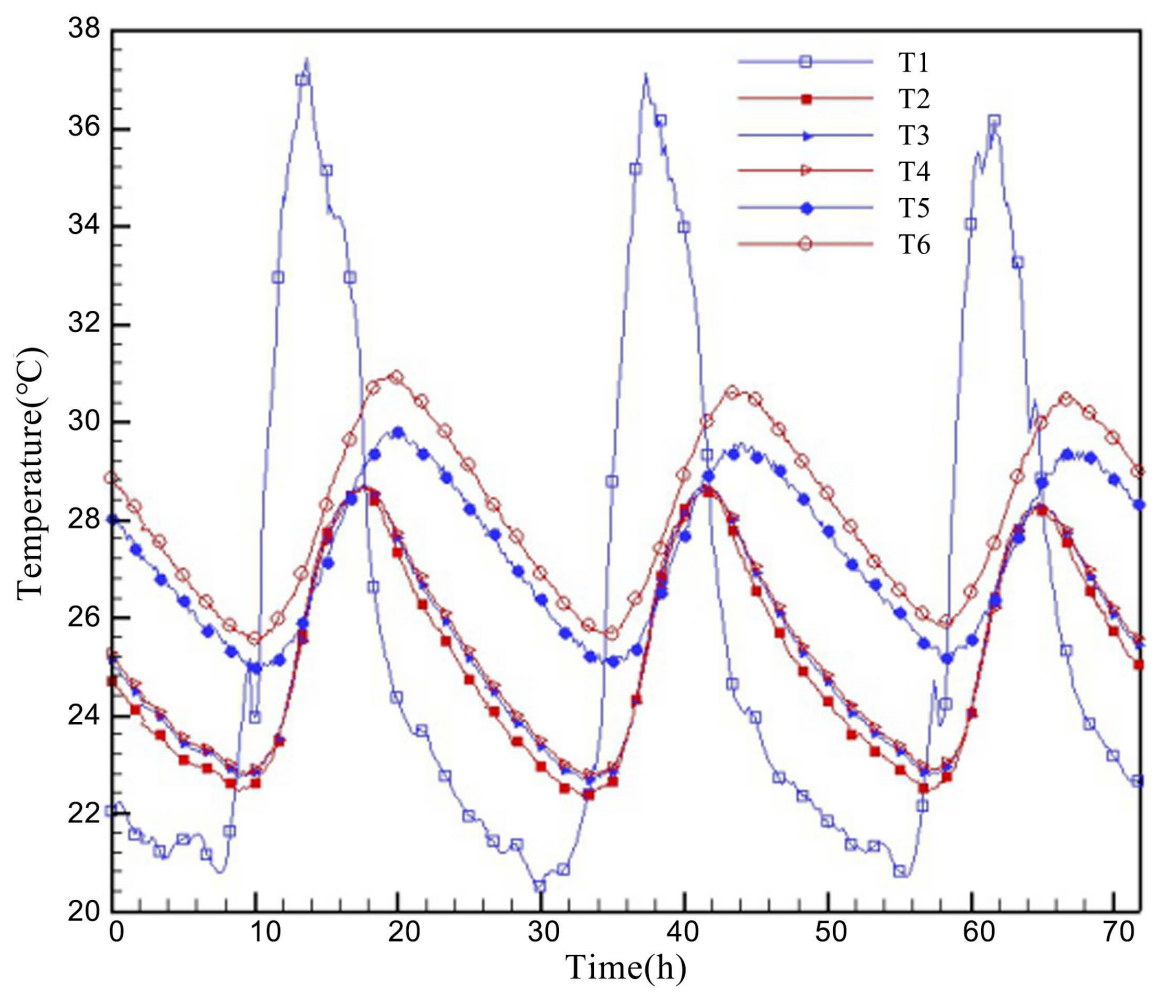

Figure 7. Time variations of the temperature through the southern wall.

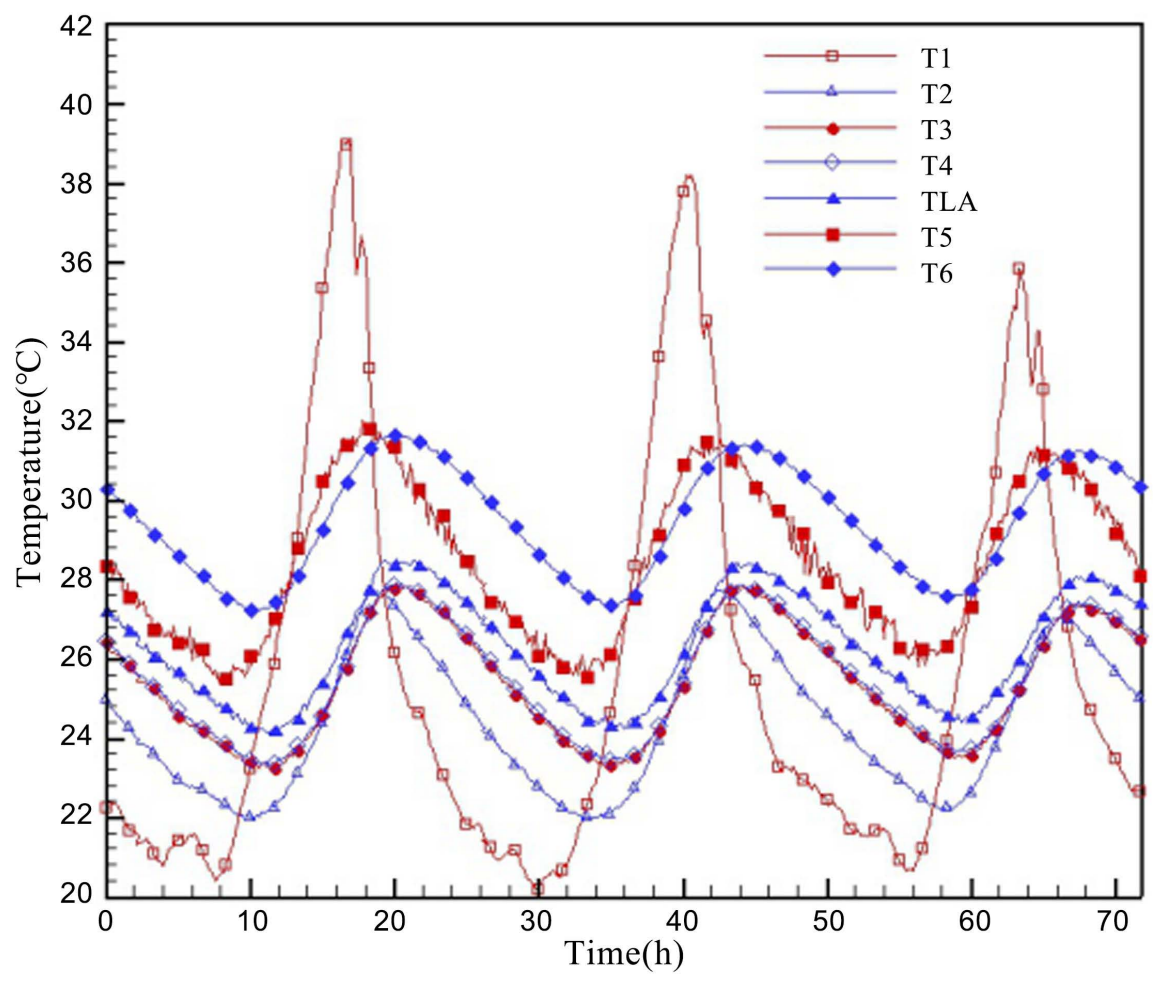

Figure 8. Time variations of the temperature through the western wall.

temperature of the room which is subjected to the external heat flux coming from the ceiling; this is visible on the oscillations in phase with the temperature 
$\mathrm{T}_{1}$ of the outer face of the extern wall.

We recall that we have placed 3 thermocouples inside the western wall air layer as indicated above (Figure 3). Figure 9 shows the temperature variations with time for these thermocouples. These thermal variations, in the middle part of the air layer, show that the air gap evolves as a function of the solar flux received by the western wall (containing the PCM). The part of the curve corresponding to a constant temperature in the middle part extends from 12:00am to $4: 00 \mathrm{pm}$ (corresponds to a line segment), the air layer is stratified. The maximum of the indoor temperature $\mathrm{T}_{\max }=27^{\circ} \mathrm{C}$ is around 7:00pm, while the maximum temperature of the western outside face is equal to $35.9^{\circ} \mathrm{C}$ and it reached around 5:00pm. In addition, the outdoor temperature reaches its maximum of $25.2^{\circ} \mathrm{C}$ at 2:00pm. This shows the effect of the thermal inertia when the PCM is introduced inside of the air layer of the wall.

By comparing the temperature curves of Figure 7 and Figure 9, it can be seen that Case 2 is composed of three walls, two of brick and the third of thin air layer, whereas the Case 1 is composed of only two brick walls separated by a convective air layer.

\section{Conclusions}

This study intends to support the application of phase change materials (PCM) in building as passive alternative to maintain the thermal comfort with a significant reduction of energy losses to the outside and as a result of significant savings in heating energy.

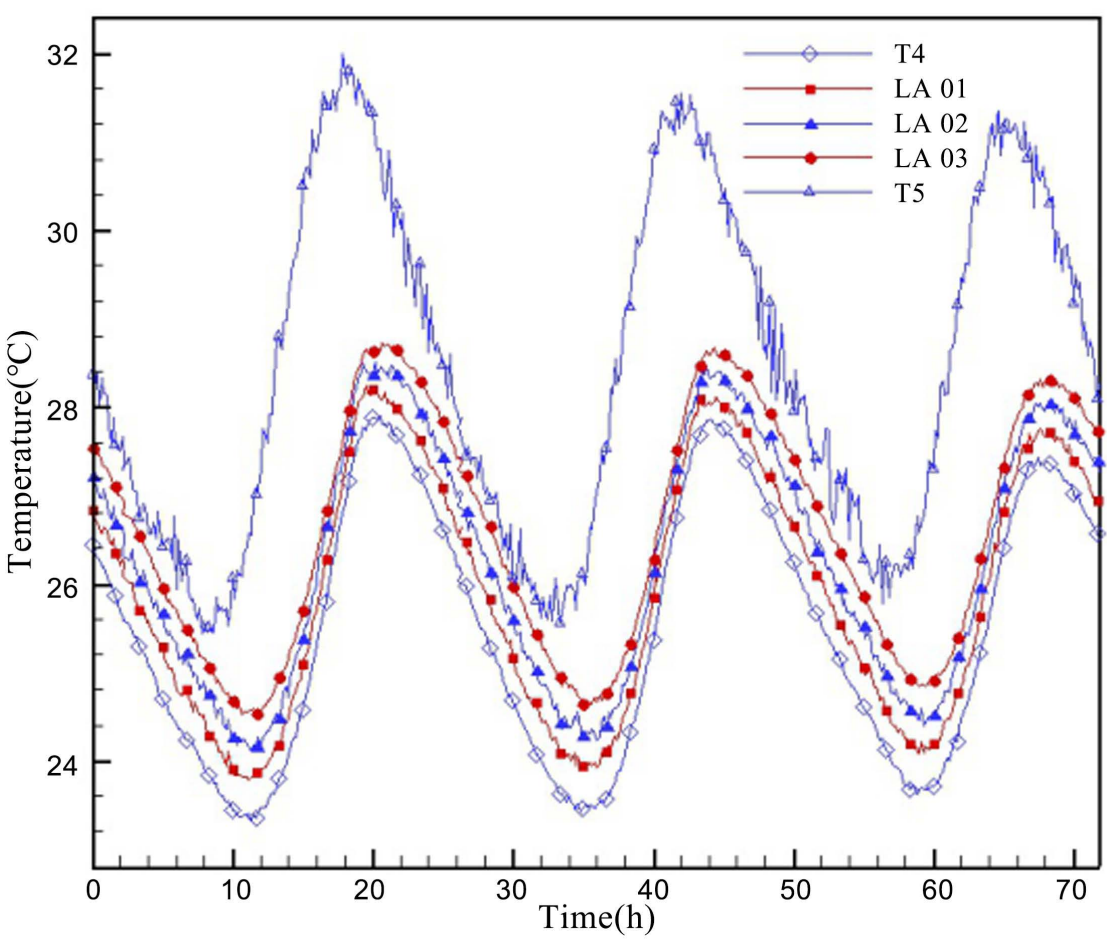

Figure 9. Temporal variation of temperatures inside the air layer, September $23^{\text {th }}$ to $25^{\text {th }}$, 2017. 
The experimental results presented in this study showed the ability of PCM to increase the thermal inertia of the walls. Significant reductions of heat fluxes through the walls with PCM, are due to absorption of heat in this latter. It can, therefore, be concluded that PCM is effective for storage of heating gains/losses, and improvement of thermal comfort.

The use of PCM as a means of storage and thermal insulation was carried out according to two approaches: the PCM is separated from the outer wall of a wall by a thin air layer (Case 2) or glued directly to this wall (Case 1). The results of the study show that Case 2 is by far more favorable than Case 1. In the latest case, the air gap adopted in buildings in Morocco has no role in thermal insulation: convective transfers are developed. Case 2 shows that the thickness of the air gap is a decisive parameter for thermal insulation in double-walled walls. The application of such materials for construction makes it possible to improve thermal comfort and reduce the load of Heating, Ventilation and Air-Conditioning (HVAC) systems for saving electric energy.

\section{Conflicts of Interest}

The authors declare no conflicts of interest regarding the publication of this paper.

\section{References}

[1] ONEE (Office National d'Electricité et de l'Eau) (2010) Energetic Statistics. https://www.one.org.ma

[2] Elamin, M. (2014) Contribution à l'évaluation énergétique des bâtiments au nord du Maroc: Cas de la ville de Tanger. Doctoral Thesis, Tangier, Morocco.

[3] Bekkouche, S.M.A., Benouaz, T., Cherier, M.K., Hamdani, M., Yaiche, M.R. and Benamrane, N. (2012) L'apport de l'émissivité thermique, cas d'un mur type opaque muni de cavité d'air. Revue des Energies Renouvelables, SIENR'12 Ghardaîa, 29-39.

[4] Hausladen, G., Saldanha, M., Liedl, P. and Sager, C. (2005) Climate Design: Solutions for Buildings That Can Do More with Less Technology. Birkhauser, Munich.

[5] Castell, A., Martorell, I., Medrano, M., Perez, G. and Cabeza, L.F. (2010) Experimental Study of Using PCM in Brick Constructive Solutions for Passive Cooling. Energy and Building, 42, 534-540. https://doi.org/10.1016/j.enbuild.2009.10.022

[6] Cabeza, L.F., Castellon, C., Nogus, M., Medrano, M., Loeppers, R. and Zubillaga, O. (2007) Use of Microencapsulated PCM in Concrete Walls for Energy Saving. Energy and Building, 39, 113-119. https://doi.org/10.1016/j.enbuild.2006.03.030

[7] Ahmad, M., Bontemps, A., Sallée, H. and Quenard, D. (2006) Thermal Testing and Numerical Simulation of a Prototype Cell Using Light Wallboards Coupling Vacuum Isolation Panels and Phase Change Material. Energy and Building, 38, 673-681. https://doi.org/10.1016/j.enbuild.2005.11.002

[8] Kuznik, F., Virgone, J. and Roux, J.J. (2006) Energetic Efficiency of Room Wall Containing PCM Wallboard: A Full-Scale Experimental Investigation. Energy and Building, 40, 148-156. https://doi.org/10.1016/j.enbuild.2007.01.022

[9] Mourid, A. and El Alami, M. (2017) Experimental Analysis of the Thermal Behavior of Two Cavities Kind of Living Space with and without PCM on Envelopes. International Journal of Modern Embedded System, 5, 2320-2005. 
[10] Pasupathy, A., Athanasius, L., Velraj, R. and Seeniraj, R.V. (2008) Experimental Investigation and Numerical Simulation Analysis on the Thermal Performance of a Building Roof Incorporating Phase Change Material (PCM) for Thermal Management. Applied Thermal Engineering, 28, 556-565. https://doi.org/10.1016/j.applthermaleng.2007.04.016

[11] Mourid, A. and El Alami, M. (2017) Thermal Behavior of a Building Provided with Phase Change Materials on the Roof and Exposed to Solar Radiation. Journal of Solar Energy Engineering, 139, Article ID: 061012. https://doi.org/10.1115/1.4037905

[12] Mourid, A., El Alami, M. and Najam, M. (2016) Passive Study of Energy Efficiency of a Building with PCM on the Roof during Summer in Casablanca. Journal of Power and Energy Engineering, 4, 26-37. https://doi.org/10.4236/jpee.2016.48003

[13] Entrop, A.G., Brouwers, H.J.H. and Reinders, A.H.M.E. (2011) Experimental Research on the Use of Micro-Encapsulated Phase Change Materials to Store Solar Energy in Concrete Floors and to Save Energy in Dutch Houses. Solar Energy, 85, 1007-1020. https://doi.org/10.1016/j.solener.2011.02.017

[14] Athienitis, A.K., Liu, C., Hawes, D., Banu, D. and Feldman, D. (1997) Investigation of the Thermal Performance of a Passive Solar Test-Room with Wall Latent Heat Storage. Building and Environment, 32, 405-410. https://doi.org/10.1016/S0360-1323(97)00009-7

[15] Mourid, A., El Alami, M. and Kuznik F. (2018) Experimental Investigation on Thermal Behavior and Reduction of Energy Consumption in a Real Scale Building by Using Phase Change Materials on Its Envelope. Sustainable Cities and Society, 41, 35-43. https://doi.org/10.1016/j.scs.2018.04.031

[16] Lee, K.O., Medina, M.A. Raith, E. and Sun, X. (2015) Assessing the Integration of a Thin Phase Change Material (PCM) Layer in a Residential Building Wall for Heat Transfer Reduction and Management. Applied Energy, 137, 699-706. https://doi.org/10.1016/j.apenergy.2014.09.003

[17] Kuznik, F., Virgone, J. and Johannes, K. (2010) Development and Validation of a New TRNSYS Type for the Simulation of External Building Walls Containing PCM. Energy and Buildings, 42, 1004-1009. https://doi.org/10.1016/j.enbuild.2010.01.012 